\title{
Citizen Participation in Medium-Term Local Development Plan in Indonesia
}

\author{
Rusnaini \\ Universitas Sebelas Maret \\ Surakarta, Indonesia \\ rusnaini@staff.uns.ac.id
}

\begin{abstract}
The research on citizen participation in the medium-term local development plan is an attempt focusing on citizenship knowledge and skill. The method employed in this research was qualitative one supported by library study and supporting documents with data triangulation corresponding to the problem discussed. The analysis on prospect change was conducted through exploring the local government elite's practice and attitude currently in improving the citizen participation. The analysis was equipped with qualitative research on the experience and aspiration of local government and apparatus related to the public participation - either positive or negative. Studies show that participation in RPJMD a community contribution in thought. This participation is on the level of the fifth, namely Placation. Placation is simply a higher level tokenism because the ground rules allow citizen to advise, but retain for the powerholders the continued right to decide.
\end{abstract}

Keywords- Citizen Participation; Local Medium-term Development Plan, Good Governance

\section{INTRODUCTION}

Citizen participation is discussed more frequently after the campaign of good governance by the World Bank or United Nation Development Bank (UNDP) stating that one characteristic of good governance is participation. Many theories stating that citizen participation has a positive effect on the quality of democracy. Citizen participation is usually considered as a valuable element of democratic citizenship and democratic decision making. However, according to Rusnaini [1], democracy, in principle, emphasizes on the characteristics of the community, particularly in the national development process.

In Indonesia, a discourse about citizen participation and control over government emerges throughout the country from central to local areas since the issuance of Law Number 32 of 2004 about Local Government. One emphasis on local autonomy implementation is on citizen participation constituting the absolute precondition that should be undertaken by Regency and Municipal areas as the focus of local autonomy implementation in Indonesia in creating a democratic life at regency and municipal levels. In the last decade, Indonesia has obtained experience with citizen participation in the form of forum, collaborative order, participative budgeting, and other models in which the citizens have a more straightforward voice.
As has been known, national development is planned and implemented based on some mainstreaming. This mainstreaming serves as a principle being the soul and spirit coloring various development policies in any development sectors. In practice, these mainstreaming principles are directed to be reflected in the output of national development policy. The mainstreaming involves three points: (1) sustainable development mainstreaming; (2) good governance; and (3) gender mainstreaming.

Surakarta Municipal Government (thereafter called Pemkot) is one of areas undertaking those three mainstreaming. Specifically for sustainable development mainstreaming, through Collective Regulation between Research and Technology and Interior Ministers, the Government attempts to improve the local government's capacity, particularly in relation to the attempt improving the areas' competitiveness. Regarding this, on April 2016, Local Planning and Development Agency, thereafter called Bappeda of Surakarta held a public hearing named Public Consultation for Local Medium-Term Development Plan of Surakarta City in 2016-2021. Despite the vague final result, Surakarta Municipal Government should be praised for its attempt of involving the citizen participation in this public hearing forum named Public Consultation. Surakarta Municipal Government encourages the improvement of urban public participation in developing Local Regulation (thereafter called Perda) RPJMD of Surakarta City in 2016-2021. Parade RPJMD will be later a reference for developing a Strategic Plan for Local Apparatus Work Unit (SKPD) and next five-year Work Plan all at once. The participants involved in public consultation forum are SKPD, DPRD, LPMK, Stakeholders, and people representative.

This citizen participation program is launched with the underlying assumption that if a citizen is involved actively in developing Public Consultation forum, a RPJMD Development process will be more democratic and more effective. Both local government and community view that citizen participation in developing policy resulting in many important benefits. The citizens are expected to contribute positively to the process of RPJMD development, and its implementation will in turn confirm the performance of Surakarta Municipal Government, particularly in good governance. This article explains citizen participation level in the process of developing RPJMD of Surakarta City. 
Conyers [2] presents three (3) reason why community participation in planning has very important properties: 1 . The community is a tool to obtain information about the condition, needs and attitudes of the local community. 2. The public will trust the program development activities if they involved in the preparation and planning, because they will be more aware the ins and outs of the program activities and will have a sense of belonging to the activity program. 3. Encourage citizen participation because one might think that is a right democracy when the people involved in the development

Citizen participation seems to play an important part in decison making related to public affairs in developing the belief that public involvement will result in more public preferences. The community is expected to contribute positively to the process of drafting RPJMD, and its implementation in the future can strengthen the performance of Surakarta City Government, particularly in good governance.

Article 96 of Law No. 12 of 2011 on legislation concerning citizen participation in the formulation of legislation. Citizen participation is very important in order to create good governance. However, for this community is only used as a tool to legitimize power and as the object of any government policy which is not considered the interests of society itself. In fact, people should have a very important role in the implementation of regional autonomy for the country's sovereignty belongs to the people. Evident was finding a lot of collaborative practice is still associated with the need to comply with legal obligations, not necessarily meet their needs.

Research with a focus on citizen participation has been widely performed. However, there are differences in the characteristics of research on citizen participation. Oh, and Lim [3] suggested that citizen participation has been recommended as an important democratic reform to scholars and practitioners. Despite the importance of citizen participation mechanism, the relationship between administrative participation and political participation needs to be studied. Oh, and Lim connected the disconnected link empirically by examining the role of political efficacy mediation between two citizen participation types. Connecting administrative and political participation through political efficacy, they suggested that citizen participation in administration plays an important part in dealing with the lowered political participation. For empirical test, crosssectional data were collected from local Korean jurisdiction using a survey with a questionnaire, and a series of Structural Equation Modeling was used to identify a causal relationship between those variables. Their finding reveals that administrative participation affects political participation only through political efficacy, while the demand for administrative participation is related to political participation, either directly or through internal political success. Otherwise, political participation grows administrative participation through political efficacy only. Considering empirical evidence, administrative administration and political participation confirm each other, and political efficacy plays an important part in mediating the two types of citizen participation. Participation is interpreted broadly referring to the community's involvement in 'formulation process, part and implementation of public policy'. Oh, and Lim highlighted theoretically the lost coin between administrative and political administrations. They recommend the practitioners to realize that designing an authentic administration program is the useful way to improve the fading democratic participation. Practitioners should demonstrate many specific ideas concerning how to grow political efficacy of citizens through citizen participation. By doing so, community can be built politically, leading to their improved participation. Oh and Lim's study explored the potential benefit of democracy resulting from public participation mechanism beyond normative and instrumental advantages.

Research by Michels [4] distinguished four types of democratic participation: referendum, deliberative forum, collaborative order, and participative budgeting. He explained the effect of public participation in democratic quality and offered a systematic analysis on the contribution of democratic element's participation, like the effect on decision making, inclusion, skill and good deeds, discussion, and legitimacy. He concluded that the contribution of democratic participation is different depending on democratic innovation types. Michels suggested that citizen participation has a number of positive effects on democracy: improving civic knowledge and skill. Michels' analysis explained that the contribution of democratic participation is different from democratic participation types: deliberative forum and survey seem to promote more argument exchange, while referendum and participative policy gives the citizen the best opportunity in the process of developing policy and involves more people. However, the clear positive effect is only for those taking part, and the participants usually consist of certain small unrepresented groups; therefore the benefit of individual democratic citizenship is far more convincing than the democratic benefit in general.

In contrast to Michels, Irvin and Stansbury [5] found two advantage levels to consider (process and product) and two beneficiaries (government and citizen) in evaluating the effectiveness of public participation process. At the process level, the advantages the citizen gets are: (1) education (learning from and informing to government's representative); (2) lobbying and illuminating the government; and (3) acquiring skill for activist citizenship. Meanwhile the advantages the government gets are: (1) learning form and informing to citizen); (2) persuading the citizen, building trust and removing anxiety and hostility; (3) building strategic alliances; and (4) obtaining legitimacy or decision. At outcome level, the advantages the citizen gets are: (1) ceasing stagnation, achieving the result; (2) obtaining control over policy process; and (3) developing policy and implementing the decision better. Meanwhile the advantages the government gets are: (1) ceasing stagnation, achieving results; (2) avoiding litigation cost; and (3) developing policy and implementing the decision better. 
In order to implement good governance or practices in the implementation of the management authority of state administration affairs in politics, economics, and administration at all levels, it is important for the government to apply the principle of citizen participation. Thus the government is treating people as subjects and not merely objects of development.

Based on the background described above, this study focused to examine the extent of community involvement in RPJMD. Remission problem is how the level of citizen participation in the process RPJMD Surakarta?

\section{THEORETICAL PERSPECTIVES \\ Participation Concept}

Terminologically, participation is the manifestation of willingness to develop democracy through a decentralization process in which planned expansion is attempted from the bottom by involving community in its community planning and development process [6]. Enthusiasm to integrate citizen participation in decision making democracy is not limited to the US, but also many other countries have broad initiative in involving the public in government process. Strange [7] suggested that the emphasis on citizen participation has been followed-up by Jacksonian democratic theory. Citizen participation in government requires the presence of citizen participation in the decisionmaking process. In practice, collaboration between government and community, transparency is a certainty. Many countries refer to transparency, not only as the right to access information, but also as the means of improving the government's efficiency and accountability.

New emphasis on decentralized decision making expands the citizen participation in national development without considering education or status as the characteristics of democratic government. Loudness et al. [8] introduced a fundamental change in local democratic practice intended to change the local government's culture and attitude in creating new opportunity for democratic participation. The history of local government in England has been passed through experiments in public participation and consultation. Ostrander [9] argued that it is important to emphasize on the institution and initiative of community associations in relation to local government. It is intended to resist the current emphasizing more on government initiative. As documented by other scholars from collaborative order types, it hazardously results in computation, placation, inadequate real authority, no diversity, and poor overall parity with government.

Sherry R. Arnstein expands citizen participation based on the community's power to determine a final product. Those eight citizen participation ladders are illustrated as follows:

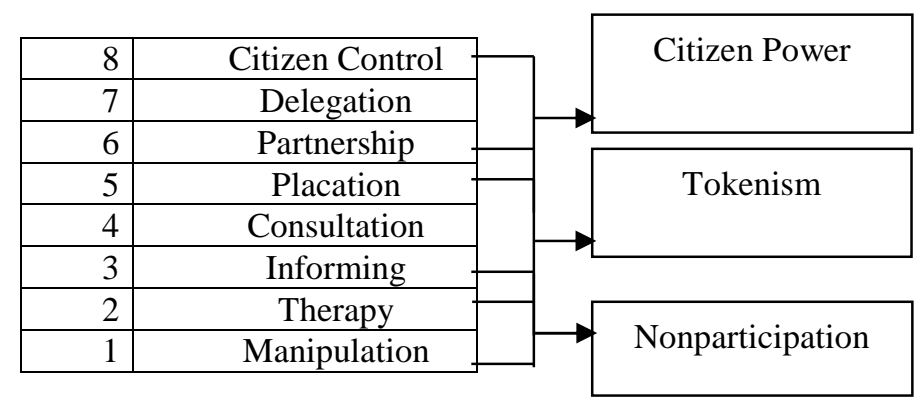

Figure 1. Degrees of Citizen Participation [10]

The explanation of each participation level can be summarized as follows: manipulation can be defined (relatively) as neither communication nor dialogue exists; Therapy is defined as there has been communication, but still limited, the initiative comes from government and in only oneway; information implies that communication has occurred in one-way only; Consultation means that communication has been two-way in nature., but Arnstein still feels this is just a window dressing ritual; Placation means that communication has run well and there has been negotiation between community and government; Partnership is the condition in which Government and community are equal partners; Delegated Power means that the government gives the community an authority in dealing with its needs itself; and Citizen Control means that the community masteries public policy from formulation and implementation evaluation and control.

\section{Medium-term Local Government Plan (RPJMD)}

RPJMD (Rencana Pembangunan Jangka Menengah Daerah $=$ Medium-term Local Government Plan) is local development plan document for 5-year period containing the explanation of vision, mission and program of local leader referring to RPJP (Local Long-Term Development Plan) and considering RPJM National (National Long-Term Development Plan) (Article 1 Number 4 of Law Number 17 of 2007 about National Long-Term Development Plan in 20052025). RPJMD emphasizes on the importance of translating wisely the vision, mission, and agenda of selected Local Leader into development objective, goal, strategy, and policy responding to the community's need and aspiration and consensus about performance parameter to measure the successful local development in the next 5 years.

Those three process plots require different approaches, but interact with each other to result in an integrated RPJMD: (1) Strategic Process Plot, constituting the domination of local planners and local planning practitioners. This plate is intended to yield information, analysis, projection, objective alternative, strategy, policy, and program The participative Process plot, is the one for public participation in local planning process. This plot is a series of public participation or participatory planning event to provide consensus and agreement for important stages in the planning 
decision making. This plot becomes the means for stakeholders, NGO, CSO or CBO, to contribute effectively to any participative planning, event opportunities, and then to reevaluate and to evaluate the product of a strategic process corresponding to the planning, technical norm expectedly giving input to participative process plot; This plot is a series of public participation or participatory planning event to provide consensus and agreement for important stages in the planning decision making. This plot becomes the means for stakeholders, NGO, CSO or CBO, to contribute effectively to any participative planning, event opportunities, and then to reevaluate and to evaluate the product of a strategic process corresponding to the planning, technical norm expectedly giving input to participative process plot; This participative process plot is the spirit underlying the issuance of the Local Autonomy Act (Law) In Indonesia. This law builds on the apprehension that so far community is only made a means of legitimating power and the object of any government policy not taking into account the community's interest. Meanwhile, community (public) should play a very important part in the implementation of local autonomy because our country's sovereignty is in the people's hands. It can be seen from many collaborative practices still related to the need for complying with legal obligations in the implementation of Local Autonomy that have uncertainly met the citizen's need..

\section{Good Governance Concept}

Generally, the definition of good governance is everything related to the action or conduct that is directed in nature, controlling or influencing public affairs in order to realize values in daily life [11]. United Nation Economic and Social Commission for Asia and the Pacific (UNESCAP) [12] stated that in the last decade, the term governance and good governance developments related to the implementation of government in a country. Governance is the decision making process and the process of how the decision is implemented or not implemented at various levels of government. Government is one of governance actors, while the other ones are: non government organization, community leader, religion leader, university, cooperative, and others related.

\section{Methodology}

The method used in this research was a qualitative research method supported with library study and document, with data triangulation technique corresponding to the problem discussed. To measure the participation level, Eight Rungs on the Ladder of Citizen Participation from Arnstein were used. The sample was taken based on the division of Surakarta City's area into five sub districts. Respondents were selected using purposive technique, while from Local Government of Surakarta City the respondents consisted of the officers of Surakarta City's Local Planning Agency, in this case belonging to monitoring and evaluation (monev) sub division. Data analysis was carried out using frequency distribution with a percentage of each sector questioned in the questionnaire. The next step is to analyze and to process data crosschecked with the predetermined assessment scale. The technique of analyzing data the writer used was inferential analysis. To measure the degree of Surakarta City's public participation in developing RPJMD through holding the Public Consultation Forum uses Sherry R. Arnstein's degree of participation, a questionnaire was developed based on three stages of public participation degree theory.

\section{FINDINGS AND DISCUSSION}

Vision RPJMD Surakarta Surakarta 2016-2021 is the realization as a city of culture, independent, advanced, and prosperous. Its mission is divided into five, namely: waras, wasis, wareg, mapan, and papan. Waras, meaning that people realize that healthy physically and spiritually in a healthy environment. Wasis, means to realize the people who are intelligent, skilled, noble character, character and contribute to the advancement of the competitiveness of the city. Wareg, that is, to create a society productive city is able to meet the basic needs of physical and spiritual self and participatory society towards building the welfare of the city. Mapan, meaning that embodies governance and civilized society Adi noble toward city life that is just, accountable, orderly, safe, convenient, and competitive. Papan, that is, the board needs to achieve balance and the carrying capacity and environmental capacity to the dynamic needs of the population growth towards sustainable development-minded city. The fifth mission is realized by applying five things, namely steady honesty, discipline steady, steady service, steady organization, and steady cooperation.

The development of RPJMD is implemented by involving the community (and entire stakeholders) in planning, decision making in all of the planning stages. RPJMD development also involves a consultation process with political power, particularly Local Leader (Mayor) of Surakarta and Local Legislative Assembly. On the one hand, the planning is Bottom-Up in nature based on community's aspiration and need, but on the other hand, it is Top-Down because the RPJMD development process is synergy with the higher strategic plan: RPJM Nasional. In other words, to achieve consistency and integration of medium-term planning, annual planning and budgeting, RPJMD uses analysis and program framework similar to that in RKPD, SKPD (Annually Development Program of Local Government Agency), General Budget Policy and APBD (Local Income and Expense Budget). The analysis framework proposed for RPKMD employed the separation of function, compulsory affairs and optional affairs of local government. The functions of local government include: public service, orderliness and safety, economy, living environment, housing and public facilities, health, tourism and culture, education, and social protection. Thus, there are 3 specific plots in developing RPJMD: strategic technocratic process, participative, and legislative and political plots. If we compare United Nation Economic and Social Commission for Asia and the Pacific (UNESCAP) within characteristics of good governance and what has been practiced in Indonesia, beyond of compliance. Even though 
such conditions are debatable, process RPJMD actually are proper to be evidences how weak the implementing of good governance concept in this country. If we compare United Nation Economic and Social Commission for Asia and the Pacific (UNESCAP) within characteristics of good governance and what has been practiced in Indonesia, beyond of compliance. Even though such conditions are debatable, process RPJMD actually are proper to be evidences how weak the implementing of good governance concept in this country.

The findings show that citizen participation is carried out in a public consultation forum on April 8, 2016. The citizen has provided input in the form of ideas, information, advice, criticism and assessment on the proposed program RPJMD. To get around the limitations of time face-to-face only lasted one day, people can send a proposal in writing and send it to the email Surakarta Regional Development Planning Agency. It appears that citizen participation is not ideal because the existing participatory mechanisms are not enough to give space for the people. It allows citizens to advise or make suggestions, but still the authorities the right to judge the legitimacy or feasibility of the advice. People are not involved in full up to the decision-making. Decisions about RPJMD only negotiations between the executive and the legislature. Referring to the theory of eight stairs participation of Arnstein, level of participation in the fifth, which placation. This means that the communication has to be two-way between the government and the citizen in public consultation forum where they discuss the agenda of local government. But the decision remains in the hands of the government. At this level of citizen participation has been incurred but not yet certain whether their aspirations will be accepted or not by the government arena planning process is still ongoing until the budgeting process and still allow for a decision of the ruling party. The challenges of citizen participation in RPJMD is equality and partnership.

\section{CONCLUSIONS}

This article examines citizen participation in RPJMD in relation to good governance in Surakarta. Firstly, the development of Surakarta City's RPJMD is closely related to the process of determining where the area will be directed to in relation to its development and what to be achieved in the next 5 years, how to achieve it, and what strategic measures to take in order to achieve the objective.

Secondly, at level Placation, the community has direct involvement in the planning process that is in the public consultation forums though decision-making is still determined by Surakarta Regional Development Planning Agency.

\section{REFERENCES}

[1] Rusnaini. 2015. Democracy and Local Autonomy Policy in Indonesia: A Particularist Perspective. Advances in Social Science Education and Humanities Research, Volume 34, pages 364-368.

[2] Conyers, Diana. 1994.Perencanaan Sosial di Dunia Ketiga: Suatu Pengantar.Yogyakarta: Gadjah Mada University Press. P. 154-155.

[3] Oh, Y and Lim, S. 2016. Connecting a missing link between participation in administration and political participation: the mediating role of political efficacy. International Review of Administrative Sciences April 18, 2016.

[4] Michels, A. 2011. Innovations in democratic governance: how does citizen participation contribute to a better democracy? International Review of Administrative Sciences June 2011 vol.77 No. 2, pages 275293.

[5] Irvin, R.A and Stansbury, J. Citizen participation in decision making: is it worth with the effort? Public Administration Review. Volume 64. Issue 1, pages 55-65. February 2004

[6] Tilaar, HAR. 2009. Kekuasaan dan pendidikan: kajian manajemen pendidikan nasional dalam pusaran kekuasaan. Jakarta: Rineka Cipta.

[7] Strange, J.H. 2006.The impact of citizen participation on public participation on public administration.Public Administration Review.Volume 32. Special issue: Citizens action in model cities and CAP programs: case studies nd evaluation. (September 1972) 457-470.

[8] Lowndes, V, Pratchett, L, Stroker, G. Trends in public participation: part 1-local government perspectives. Public Administration. Volume 79. Issue 1, pages 205-222. Spring 2001.

[9] Ostrander, S.A. 2013. Agency and initiative by community associations in relations of shared governance: between civil society and local state. Community Dev J (2013) 48 (4):511-524.

[10] Arnstein, S.R, 1969. Eight rungs on ladder of participation. Journal of the American Planning Association, Vol. 35, No. 4, July 1969, pp. 216224 ..

[11] Sedarmayanti, 2003.Good governance dalam rangka otonomi daerah. Bandung: PT mandar maju.

[12] Nugraha, $\mathrm{N}$ et al. 2005. Hukum Administrasi Negara. Depok: Fakultas Hukum Universitas Indonesia 